\title{
Labor market trends in a low and heterogeneous productivity country. Evidence from Argentina's manufacturing
}

\author{
Tendências do mercado de trabalho em um país de produtividade \\ baixa e heterogênea. Evidência da produção da Argentina
}

JUAN M. GRAÑA*

RESUMO: Durante a Industrialização substitutiva (1930-1975), os salários subiram, e o desemprego e a pobreza foram baixos. Durante o “processo neoliberal” (1976-2002) a liberalização dos mercados de bens e financeiros resultou na regressão da estrutura produtiva, elevado desemprego e declínio dos salários reais. Finalmente, desde o colapso de 2002, a Argentina teve um enorme sucesso em termos do desemprego, com realizações limitadas em salários ou pobreza. Este trabalho tenta responder a por que a Argentina enfrenta dificuldades para voltar a números do mercado de trabalho do passado destacando o processo de diferenciação dos capitais e a nova divisão internacional de trabalho.

PALAVRAS-CHAVE: Salários reais; produtividade; teoria do desenvolvimento; indústria transformadora; a comparação internacional; Argentina.

ABSTRACT: During Substitution Industrialization (1930-1975), wages rose, and unemployment and poverty were low. During the "neoliberal process" (1976-2002) the liberalization of the goods and financial markets resulted in the regression of the productive structure, high unemployment and the decline of real wages. Finally, since the collapse of 2002, Argentina has had enormous success in terms of unemployment, with limited achievements in wages or poverty. This paper tries to answer why Argentina faces difficulties to return to past labor market figures highlighting the process of capital differentiation and the new international division of labor.

KEYWORDS: Real wage; productivity; development theory; manufacturing sector; international comparison; Argentina.

JEL Classification: E24; O54; O11; J31; L60.

\footnotetext{
* Researcher at Centro de Estudios sobre Población, Empleo y Desarrollo (CEPED), Instituto de Investigaciones Económicas, Universidad de Buenos Aires, Argentina. E-mail: juan.m.grana@gmail.com. Submitted: 28/July/2016; Approved: 22/May/2017.
} 


\section{INTRODUCTION}

Since the mid-seventies, Argentinean labor market has experienced two very different trends. By 1976, the military dictatorship abandoned the industrialization policies conceived and developed since 1930, and liberalized both goods and financial markets. The results observed through the next three decades were the destruction of the productive structure - particularly high value-added sectors and small and medium enterprises (SME) -, high unemployment, declining real wages and labor market segmentation ${ }^{1}$.

On the contrary, the last decade showed a reversal of those figures. After the 2002 collapse, Argentina devalued its currency - previously pegged to the American dollar- and applied policies intended to rebuild its productive sector. Although it had a tremendous - and fast - success in terms of reducing unemployment (it fell from $25 \%$ to $8 \%$ in just five years) the accomplishments regarding wages and labor segmentation were limited. Average real wages recovered pre-crisis levels in 2007 and then stagnated by 2012 with their purchasing power representing barely an $80 \%$ of 1970 's wages. Regarding labor market segmentation, Argentina still exhibits $30 \%$ informality in wage earners - up from $20 \%$ in 1970 s - and the income penalty remains above $30 \%$.

In this context, this paper tries to answer why Argentina faces so many difficulties in its intent to return to labor market figures achieved in the past, mainly regarding real wages and income distribution. To accomplish that, in the next section we will present the theoretical framework used, which revisits the initial works of Programa Regional del Empleo para América Latina y el Caribe (ILO program for Latin America, or PREALC) and the Economic Commission for Latin America and the Caribbean (ECLAC) transformed through the developments of Iñigo Carrera (2004).

In the subsequent section, we will apply those theories to Argentina in order to understand the structural limitations the country faces in its path towards a more inclusive labor market. To support these arguments we will present long-term data on labor conditions in Argentina manufacturing sector such as wages, informality and segmentation, in comparison with those of the United States.

\section{THEORETICAL FRAMEWORK}

\section{The PREALC-ECLAC framework}

By late 1960s, research on labor market emphasized a particularity of undeveloped countries: no homogeneity was to be found. From the original paper of

\footnotetext{
${ }^{1}$ We refer to "labor market segmentation" to the situation where workers with identical personal characteristics suffer wages and labor conditions differences linked to the formal or informal sector where they work.
} 
Hart (1973), the division between formal and informal sectors has been a key concept to understand this singularity. Moreover, in the 1970s, the PREALC conducted groundbreaking research on informal sectors in Latin America. From that research we adopt an operational definition of informal labor as those in small establishments - with less than five workers - and the self-employed with low levels of education (PREALC, 1978).

In spite of being thorough and enlightening, this framework left some unresolved issues. The most important, on which we will focus, is why these informal sectors exist. Originally, PREALC found its source in low productivity or subsistence familiar agriculture that represented a huge part of Latin American employment. As the urban formal sector did not create enough jobs - problem exacerbated by the rapid population growth and labor saving equipment imported from developed countries - workers were forced to remain in those sectors.

However, nowadays in most parts of Latin America - especially Argentina-, only a small part of the total employment is explained by the primary sector, population growth has declined considerably, however informal sectors keep playing an important role. In this context, the PREALC explanation proves not entirely accurate.

In fact, recent studies from the ECLAC have discarded the "urban-rural" approach and replaced it with the notion that informal labor markets endure because of intra-sectoral heterogeneity (Cimoli, 2005). In this case, the large difference in productivity among companies within each sector is what creates informal employment. According to Latin American Structuralism, this heterogeneity is one of the main characteristics of developing countries, where the most modern companies have similar productivity levels to the average of the developed ones, but the rest are considerably behind (Pinto, 1973).

Apart from those evidences, the main consensus was that informal sectors would eventually disappear due to economic development. They are, as it is commonly said, a mere result of slow economic growth like the classic paper by Lewis (1954) concluded. However, again, if we look at developed countries, we see that informal sectors exist and are important, but no subsistence agriculture, high population growth or noticeable within sector heterogeneity can be found. For example, Portes and Sassen-Koob (1987) show that in developed countries the informal sector derive from competitive strategies applied by companies to achieve lower labor costs, reducing union power and escaping regulations. Therefore, though labor market segmentation exists in both developed and developing countries, it has no apparently unique source.

In addition, the consequences on the standards of living of the informal workers are very different between developed and undeveloped countries. In the former, average wages are higher than in underdeveloped ones, so even if informal workers suffer an income penalty, they tend to be better off, and possibly remain out of poverty. That is not the case in Latin America.

Therefore, something is missing here. Is informality due to underdevelopment? An unforeseen consequence of companies' behavior, or both? Why has its relevan- 
ce increased in countries that did not have a big informal sector back in the seventies (for example, Argentina)? Moreover, why it does not disappear automatically with economic growth?

We will endeavor to answer these questions by adding - we believe - key elements to the PREALC-ECLAC framework intra-sectoral heterogeneity, international productivity gap and the transformations that occurred in the world economy since the 1970s. To lay out that theory we need to take a few steps back into economics, competition and capital differentiation ${ }^{2}$.

\section{The "missing" links}

Companies exist to make a profit, every economic theory acknowledge this. However, let us not forget that not every firm can survive competition and become profitable. As individual capitals compete with each other in order to sell their commodities, only the ones with lower costs will survive. To reduce its costs, from a political economy viewpoint, the firm has various actions that can be summarized into two groups: 1) those that increase labor productivity and 2) those that directly reduce the production costs without affecting labor power performance.

The former is linked to wage-earners cooperation, greater division of labor and the introduction of machinery and automation. The latter, implies the more efficient use of installations, inputs and wastes. In general terms, to apply them, companies need to expand their scale (and/or scope) of production. Therefore, competition forces every company to expand their size.

However, given the social demand for that commodity, not every company can expand its production because at that new larger scale the "market" is not big enough to include them all. So only, some can make it and the others tend to lag behind. This process implies constant capitals differentiation between normal and small capitals (Iñigo Carrera, 2007).

Nevertheless, once the scale and productivity gap is created, other mechanisms come into play that set those two groups of companies increasingly apart. The first one is labor productivity, as stated above. The second one is innovation. As research and development $(\mathrm{R} \& \mathrm{D})$ investment has important economies of scale, larger companies derive more benefits from those activities (Dosi, 1988). Thirdly, the access and conditions of credit and commercial channels give the largest companies a competitive edge. Therefore, capital differentiation is not only constant but also increasing.

As a result, small capitals receive a smaller profit rate and their productivity gap increases in time. Eventually the gap would be so large - and profit rate so low - that

\footnotetext{
${ }^{2}$ We will make the case of an economy, like Argentina, that evolves from a relatively homogeneous labor market with high wages and low poverty to one where segmentation implies employed workers poverty. The process is not exactly the same for an economy with an already heterogeneous labor market but conclusions can be generalized.
} 
the company must: 1) change to sectors where their costs allowed them to continue in production or 2) file for bankruptcy or be closed down by their owners and use the remaining capital to invest in banks and collect interests (Shaikh, [1991] 2006).

However, before that happens, small capitals can receive compensations for their higher costs from three extraordinary sources of surplus: 1) ground rent, 2) foreign debt and 3) labor costs (Iñigo Carrera, 2007; Graña, 2013). The first one, result of non-reproducible natural conditions enhancing labor productivity in agriculture and mining, can be transferred to industrial capitals without hindering production in those sectors (Ricardo, [1817] 2004; Marx, [1894] 2007). The second one is a source of value received from outside the country that can be used in the same way.

Finally, when the first two are not sufficient - due to low international prices or the impossibility to issue debt-, small capitals can try to obtain them from their own employees lowering wages and employment conditions. This usually is the case and labor market segmentation between small and normal capitals becomes a reality. As Portes and Sassen-Koob (1987) show workers of smaller firms tend to receive lower wages and worse working conditions; even though those firms aren't the only guilty party because most of them are part of commodity chains regulated by a big company that takes advantage of this (Starosta, 2010). However, only a segment of the labor market needs those compensations (that made up of laggard companies) average wages and work conditions continue to be regulated by the labor force value. This is the case in developed countries. This process usually goes hand in hand with labor discrimination and the workers that make up the informal sector are the least qualified as well as women, youths, immigrants or minorities (Dickens and Lang, 1984).

However, in underdeveloped countries the companies whose productivity is noticeably lower than the international standards are the vast majority. Most companies, even multinational subsidiaries, endure an important productivity gap. In that context, employment can only be created if lower wages and regulations exist; in other words if compensations are a reality. So average wages are not directly determined by labor force value, as in developed countries, because of the limits imposed upon it by the productivity gap, which explains the international diversity of wages. If it is in average small, wages and work conditions will not suffer much, but if it is large enough wages could be substantially lower.

As stated by Pinto (1973) developing economies are also far more heterogeneous in their productive capacities than developed ones. So the income penalties associated to labor market segmentation also tend to be greater and income distribution more inequitable. The combined effect of lower average wages and higher income inequality pushes informal workers into poverty. This is why in developing countries - with important productivity gaps both external and internal - workers face a dichotomy between poverty wages and unemployment ${ }^{3}$. In other words, the

\footnotetext{
${ }^{3}$ Due to the non existent comprehensive social security system, workers will forcefully choose the first one.
} 
characteristics that appear in the laggards of the developed countries constitute the bulk of the labor market in the "South".

As we implied above, the characteristics of labor market are the result of two determinations set nationally: productivity lag with international standards and internal heterogeneity. Together they will set average national wages, conditions of employment and its segmentation. However, in order to explain the trends in Argentina - on which we will focus in the next section -, we need another "ingredient": the world's economy transformations.

Since late sixties, due to various reasons that would need a paper of their own, the - until then - successful combination of Fordism and Keynesianism came into question. The resulting strategy developed by the companies in order to restore their profit rates was delocalization of production to poorer countries where wages and labor conditions were significantly lower (Fröbel et al., 1982) ${ }^{4}$.

This strategy set in motion various effects in different regions. Due to the magnitude of the extremely low wage workforce available in those countries, companies that relocated generated extraordinary surpluses. The incentive was so important that wages and labor conditions for the types of jobs that could be relocated (especially the least qualified) in the developed world stagnated or declined in the context of a permanent threat to relocated even more productions lines. Therefore, the informal workers of the developed world saw a worsening in labor conditions or, directly, unemployment.

However, in the underdeveloped world, with the exception of Southeast Asia, the already huge productivity gap was worsened because those small capitals began facing competition by commodities produced with lower costs. The wage differential between Latin America's richer countries and the newly industrialized were so large that unemployment rose and for those still employed wages fell dramatically.

\section{Theoretical summary}

Before continuing to the case of Argentina, we would like to summarize the trends we have just developed.

As capital differentiation is intrinsic to capitalism, labor market segmentation is equally permanent due to the need of small capitals to lower wages and labor conditions in order to remain in production. However, as underdeveloped economies have an average productivity gap, even among the biggest companies, the magnitude of the compensation needed has terrible consequences. Both determinations, the international productivity gap and national heterogeneity, imply that most SMEs in underdeveloped countries can only survive competition if they worsen employment conditions and pay wages that sends workers and their families into poverty.

\footnotetext{
${ }^{4}$ For a more thorough analysis of the incidence of the New International Division of Labor on Argentina, see Graña (2013).
} 
In early stages of development, like in the first half of the $20^{\text {th }}$ century, countries were relatively autarkic so the international gap could not have massive effects. Only in that context, the internal urban-rural gap pointed by early PREALC studies was the most relevant. Later, when rural migrations and mechanization diminished the importance of subsistence agriculture on employment, within sectors heterogeneity becomes the main issue for labor market segmentation and domestic wage differentials. Now, with globalization, while within sectors heterogeneity continues to explain internal segmentation, is the international productivity gap that explains average national wages determinations from where segmentation operates. In addition, there we find the explanation to why informal sectors receive a wage so low that drives them into poverty.

We will argue - after studying Argentina - that macroeconomic and industrial policies are an integral part of the policies that need to be implemented to promote inclusive labor markets. As the pressing objective for inclusive labor markets is to eliminate unemployment and labor force poverty we need to solve the international productivity gaps first.

\section{ARGENTINA'S DEVELOPMENT SCHEMES}

In this section, we will analyze Argentina's labor market performance. Before we start two methodological comments in order. First, in this section we will use manufacturing sector data to show empirical evidence on the main features of Argentina's structural characteristics. These data is used based on theoretical and practical reasons. Theoretically, as an entirely tradable sector it directly endures the competition from abroad, which puts in motion the trends explained before. In practical terms, the data is far more available and comparable, especially in the long-term ${ }^{5}$.

Secondly, we will use the United States as the proxy of a labor market conformed by normal capitals that do not in general require lowering their labor standards in order to compete ${ }^{6}$.

As we can see in Chart 1, Argentina's labor productivity in manufacturing has grown far more slowly than its American counterpart. Between 1935 and 2014, in our country it grew only $351 \%$ compared to $1.105 \%$ in America. As a result, the already massive productivity gap has grown: Argentina had relative labor productivity close to $40 \%$ in the 1930 s and only $12 \%$ in the 2010 s.

This trend is the outcome of two productivity stagnations in Argentina: 1930-1960 and 1974-1994.

\footnotetext{
${ }^{5}$ All the historical data for Argentina and United States is compiled by the author from National Accounts and its methodology is explained in Graña and Kennedy (2008) and Graña (2013).

${ }^{6}$ Of course this is not the case in every subsector because the United States has lagged against other developed countries in some sectors. But the magnitude of the productivity gap is so huge that it will not alter the results.
} 


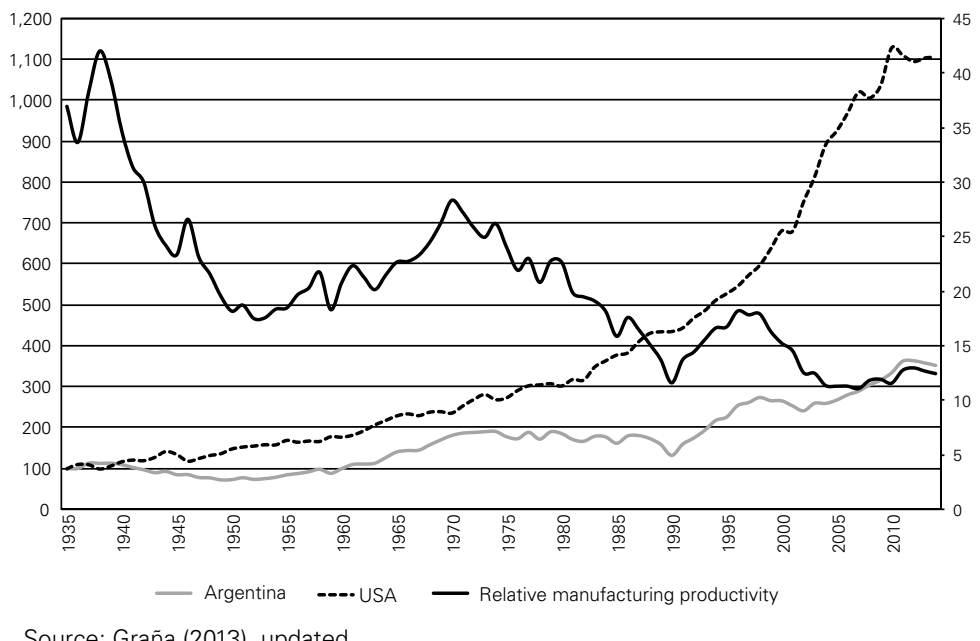

Source: Graña (2013), updated.

Following our framework, this gap comes from the different scale of the companies that operate in Argentina and in the United States. Elsewhere we presented data on this topic (Graña, 2013). As a summary, we can say that manufacturing establishments in Argentina have an average of 10 employees throughout this period, and almost $80 \%$ of all manufacturing establishments have less than that number. By contrast, in the United States, the average is almost 50 employees per establishment, and only $50 \%$ have 10 or less. In addition, the sales of the biggest manufacturing companies of Argentina represent less than $5 \%$ of their American counterparts. Finally, if we analyze the installed horse power per establishment, we will find that Argentina reaches in 1985 the same level the United States had in 1914 (Vitelli, 2012). Moreover, Argentina's manufacturing sector not only has a productive lag, but it is more heterogeneous. In Graña (2013), we also show that small establishments - those with less than 10 employees - all through the second half of the $20^{\text {th }}$ century have a productivity that represents only $40 \%$ of the average and big ones - those with more than a 100 employees - exceed the average in $40 \%$.

In other words, Argentina's manufacturing sector is comprised by small industrial capitals in need of compensation to continue in production.

The reason Argentinean companies could not reach international costs is, of course, linked to the small domestic market they supplied ${ }^{7}$. Given the original productivity gap that every late industrializer endures in the early stages of development, the small market could not provide scale or scope economies large enough for companies to export, so a vicious cycle is generated.

\footnotetext{
${ }^{7}$ Take into consideration that Argentina's population is nowadays only 40 million people and as is shown in Chart 2 the purchasing power of wages is far lower than in the United States.
} 
Chart 2: Manufacturing real wage in Argentina and United States (1935=100) and relative manufacturing real wages Argentina/US (right axis, in percentage). 1935-2014

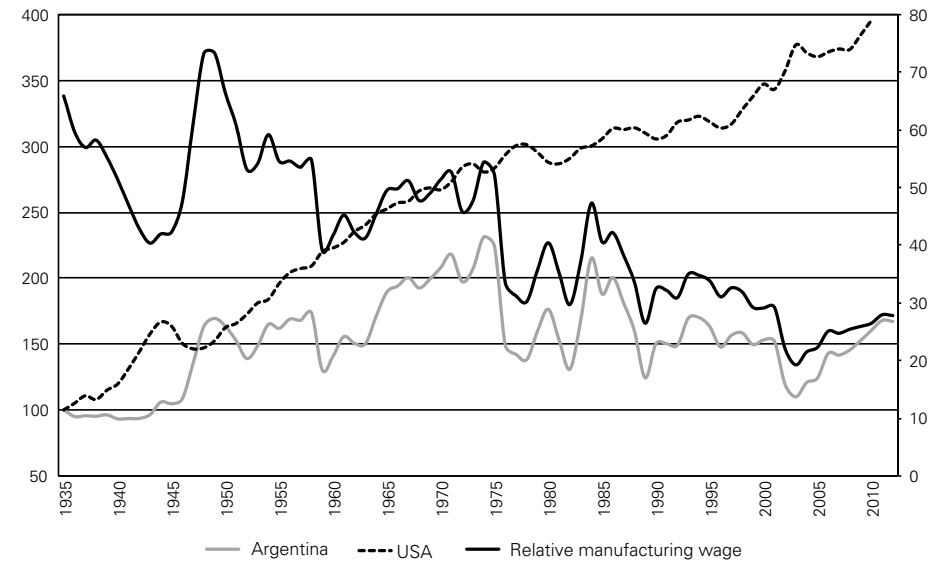

Source: Graña and Kennedy (2008) and Iñigo Carrera (2007), updated.

Even though the productivity gap has been present - and worsened - through the whole period, labor conditions and wages in Argentina had two very different trends: while experiencing a decent evolution until mid-seventies - very similar to the one observed for the United States - since then it shows a real collapse (Chart 2). Between 1935 and 2014, real manufacturing wages in Argentina grew only $73 \%$ compared to $293 \%$ in the USA; while the growth until 1970 showed $107 \%$ and $167 \%$, respectively. That is why, in the same Chart 2, the ratio of real manufacturing wages originally close to $80-90 \%$ in the 1930 s, descended to $50 \%$ in the 1970 s and to only $30 \%$ in the 2000 s.

Chart 3: Relative unit labor cost Argentina/US (1935=100), relative manufacturing real wage and manufacturing productivity Argentina/US (right axis, in percentage). 1935-2014

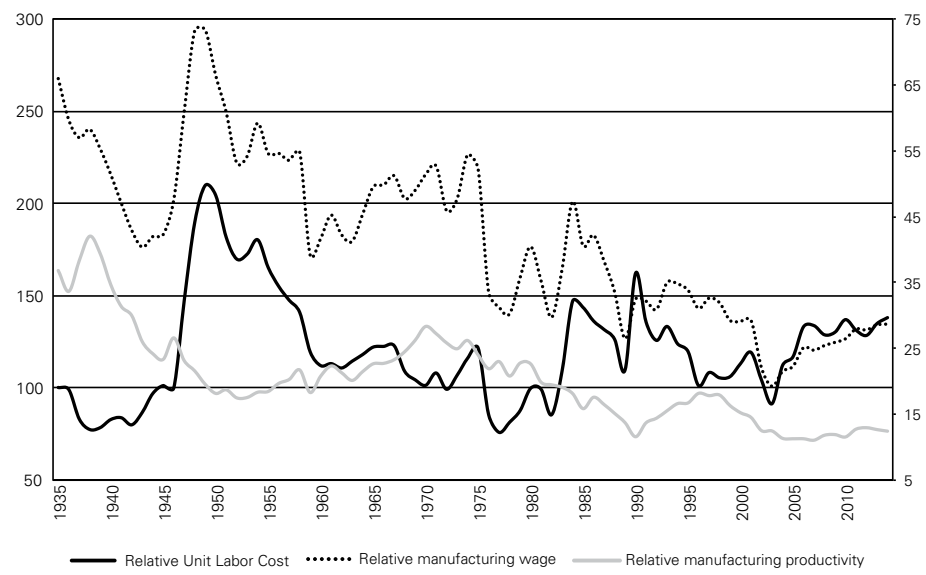

Source: Charts 1 and 2. 
In Chart 3, we present both trends - wages and productivity - and relative unit labor costs (RULC). The picture is quite clear, as productivity has lagged behind constantly the RULC evolution is determined almost exclusively by real wages, having peaked in the 1940s and again in the early 1970s. However, since then, not even the important decline in real wages has compensated the productivity poor performance. Overall, RULC is higher in the 2000s compared to the 1970s.

That brings up a fundamental question: why the Argentinean productive conditions did not influence labor market trends until the seventies ${ }^{8}$ ? To answer we need to explain briefly the main characteristics of the Industrialization scheme implemented (1930-1975) and then those of the "neoliberalism" period (1975-2003).

\section{Import Substitution Industrialization ${ }^{9}$}

Before the Wall Street Crash of 1929, Argentina's economy was almost exclusively concentrated in producing and exporting agriculture and livestock production. When international commodity prices plummeted, Argentina began implementing a different economic policy directed to industrialize the country by means of import substitution. For that purpose, the domestic market was closed to imports and income - particularly ground rent - was redistributed towards the manufacturing sector in order to promote the production and consumption of manufactured goods. Different instruments were implemented to capture ground rent, like nationalization of foreign trade or taxes on primary exports, and the government subsidized with those incomes machinery imports and supplies and applied lower transport and energy tariffs in order to compensate productive lags (Iñigo Carrera, 2007).

These two instruments, a closed economy and manufacturing subsidies, reduced - almost to zero - the foreign competition so when primary prices were high the productivity gap did not generate big problems. Nevertheless, the economy went through a crisis every time prices fell (Braun and Joy, 1968). Therefore, while the economy was growing, labor conditions and wages did not experience any limits and evolved like in any other country. Furthermore, the industrialization scheme requires high wages in order to expand the domestic market for industrial goods, since exporting was impossible due to the productivity gap.

In this context, by 1974, Argentina had developed an important manufacturing sector while labor market conditions resembled quite closely those of developed countries. Real wages were high (Chart 2) while inequality was low (Chart 7) and poverty was almost nonexistent (Chart 8).

\footnotetext{
${ }^{8}$ The other question - why Argentina couldn't catch up to the USA - is far more complex and subject to great discussion. We will try to contribute to that debate in the concluding remarks.

${ }^{9}$ For a more thorough analysis of Argentina's industrialization, see Graña (2015).
} 


\section{Neoliberalism}

However, after the 1973 oil crisis when primary commodities prices plummeted again, the possibility to continue with the ISIs scheme was dramatically reduced. Not only the disposable income to compensate had fallen but also the need for subsidies had grown with the ever-increasing productivity lag of each company ${ }^{10}$ as with the horizontal growth of the manufacturing sector as a whole ${ }^{11}$. In that new context, Argentina enters a deep economic crisis were the industrialization scheme would be dismantled.

Alongside came the "new" economic ideas of the IMF and Reagan-Thatcher administrations that promoted goods and financial market liberalizations. The combinations of those processes (crisis, military dictatorship and economic liberalization) began transforming the real wage role in the economy, from the demand-side driver of industrialization towards a cost, which needed to be reduced in order to obtain competitiveness.

On top of that, the world economy began a new stage of globalization due to telecommunications and the outsourcing to underdeveloped countries. If Argentina had a competitive problem before with products from developed countries, it was worsened since now it had to compete with productions from countries with extremely low wages.

In that context, a potentially short crisis due to a sharp decline of export prices becomes a structural one, where labor market institutions began to be dismantled and, therefore, work and living conditions began to deteriorate. The process by which it happened is the focus of the next section.

\section{LABOR MARKET AND SOCIAL INDICATORS TRENDS}

\section{The 1974-2003 period}

To analyze the long-term labor market trends in the period we present Chart $4^{12}$. The long-term trend in Argentina between 1974 and 2003 is the rise in participation, due to the flow of secondary workers trying to compensate lost household income, accompanied by important increases in unemployment and underemploy-

\footnotetext{
${ }^{10}$ Relative manufacturing productivity was only $26 \%$ in 1974 (Chart 1 ).

${ }^{11}$ By 1974 it represented $33 \%$ of total GDP and $24 \%$ of total employment, up from $20 \%$ and $14 \%$ in 1935, respectively. See Graña (2015).

12 Though Argentina's National Household Survey nowadays covers 31 cities, only the city of Buenos Aires has been surveyed since 1974. However, as it represents almost a third of national employment is a good proxy of national labor trends. The methodology for these data con be found in Graña and Lavopa (2008).

Sadly, since 2007, those figures are disputed in their quality so they should be taken with caution.
} 
ment rates. If we look at the 1974 situation, neither was relevant, representing barely $5 \%$ of economically active population. On top of that, workers without social protection grew from $23.1 \%$ until $44.1 \%$ in the same period.

Chart 4: Participation, Employment and precarious labor (left axis), Unemployment and Underemployment (right axis) rates. 1974-2014. Buenos Aires

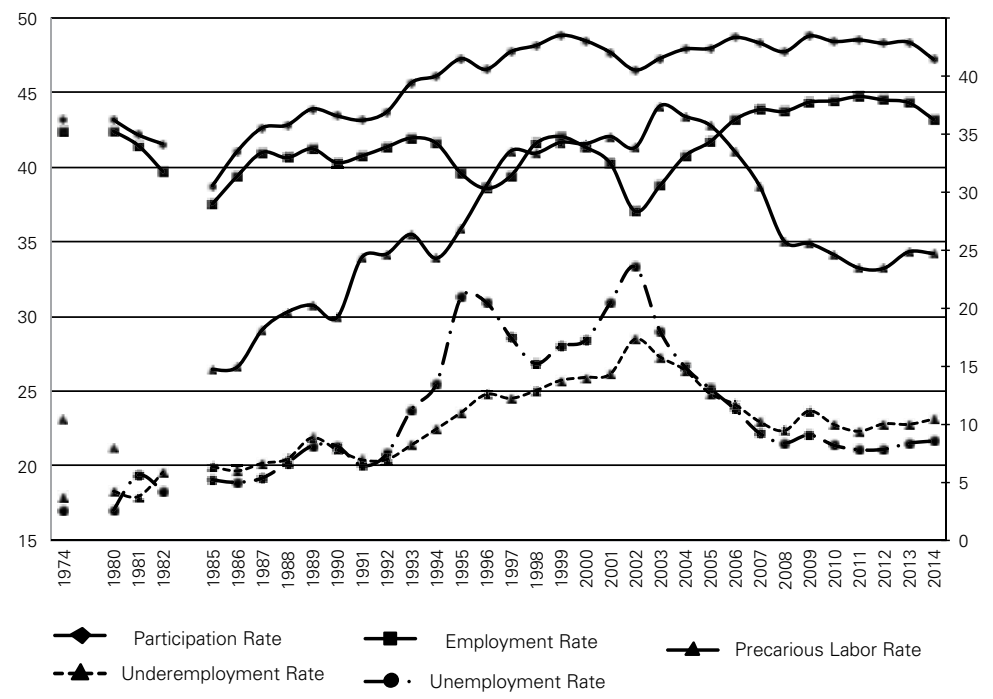

Source: Data compiled by the author based on Argentina's Household Survey (EPH-INDEC).

If we analyze the different stages within the Neoliberal period, we will find several contrasts. The first one is under the military dictatorship (1976-1983) where labor unions where banned and their leaders murdered or disappeared. The main result of this stage is the collapse in real wages as seen in Chart 2, a reduction of $43 \%$ from the peak in 1974 . However, the other rates shown in Chart 4, do not display an important deterioration; unemployment only rises to $4 \%$. In the second one, the 1980 s, in a stagflationary economy, real wages continue to decline $(-5 \%$ until 1989) but unemployment and underemployment begin to show important increases reaching $8 \%$ and $9 \%$, respectively. The nineties, a period of highly cyclical economic growth, saw the worsening of every rate. While real wages continued its trend (-4\% until 2002), unemployment rose to $23 \%$, underemployment to $17 \%$ and the rate of precarious workers to $41 \%{ }^{13}$.

Overall, we can conclude that since the abandonment of the ISI labor conditions suffered earliest regarding wages and only then, the continued downward

\footnotetext{
${ }^{13}$ Even though it is not the main focus of this article, we cannot avoid mentioning the "pro-capital" bias of labor market policy during that decade (Danani and Lindenboim, 2003).
} 
pressure began reducing jobs and their quality, ultimately leaving by 2002 a quarter of economically active workers unemployed.

Following from the first section, the deterioration of labor conditions should be especially hard for employees of the smallest firms as well for the least qualified. In the next charts, we show the trend of relative wages and formality since 1974 . As we can see in Chart 5, in the context of falling average real wages (1974-2003), workers in the biggest establishments managed to increase their relative wage, that is defend their real wages. On the contrary, workers from smaller establishments followed the overall trend, decreasing their relative wage. If we analyze the divergence among wages is especially strong during recessions or high unemployment stages, such as 1987-1989 and 1995-2002.

Chart 5: Relative wages by size of establishment $(100 \%=$ Average $)$. Buenos Aires. 1974-2014

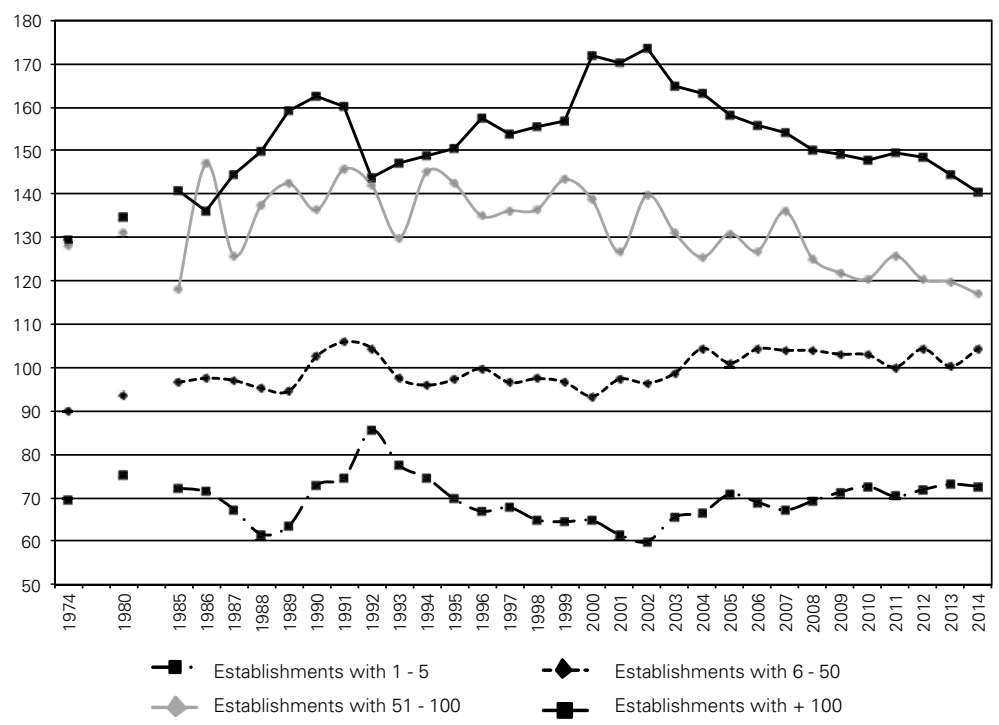

Source: Data compiled by the author based on Household Survey (EPH-INDEC).

In Chart 6, we see that formality is higher in big establishments (in the worst year, 2002 , only $10 \%$ of workers were not protected by social security) but also the trend was far more kind for those workers in comparison with smaller establishments were informality accounted for almost $70 \%$ of total employment by 2002 . In any case, precarious employment rose in every size of establishment through the 1990s given a context of liberalization of labor relations (Danani and Lindenboim, 2003; Lavopa, 2007).

Beccaria and Maurizio (2008) show the least qualified workers have endured the worst part of the crisis with declining wages, broadening income gaps and greater informality. Therefore, the literature regarding the trends in inequality is extensive and the pattern that emerges is clear. 
Chart 6. Precarious workers by size of establishment (percentage). Buenos Aires. 1974-2014

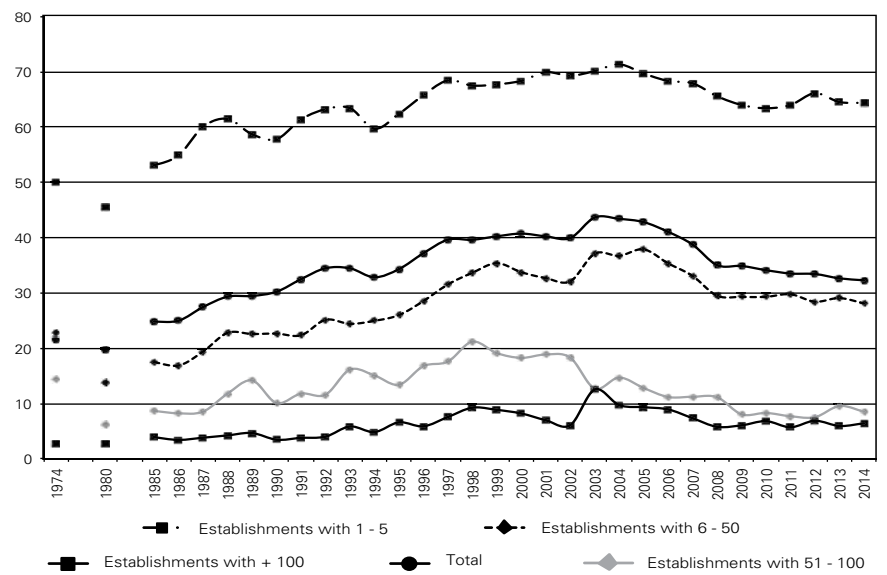

Source: Data compiled by the author based on Household Survey (EPH-INDEC)

On an aggregate basis, income inequality has indeed got worse. If we analyze the labor income Gini index, we see that it climbed from a 0.35 - very good figure for an underdeveloped country - in late 1974 to 0.52 by early 2002, just after the crisis. Moreover, as we can see the richest $10 \%$ of the employed managed to increase, in a worsening labor market, their share from $25.4 \%$ to $37.3 \%$ in the same period. While the poorest $10 \%$ experienced a decline in their already exiguous share from $2.3 \%$ in 1974 to only half by 2002. The gap between the richest decile and the poorest tripled from 11 times to 31 times in those thirty years.

Chart 7: $1^{\text {st }}$ and $10^{\text {th }}$ decile income participation, $10^{\text {th }}$ to 1 st decile gap (percentage, left axis) and Gini Index (right axis) for labor income. Buenos Aires. 1974-2014

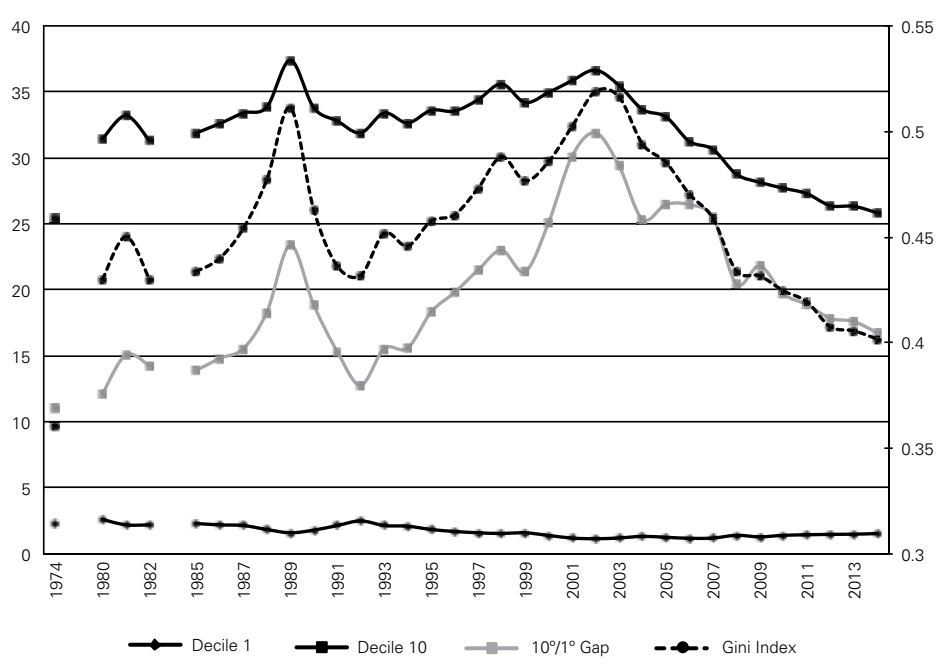

Source: Data compiled by the author based on Household Survey (EPH-INDEC). 
Chart 8: Poverty incidence (percentage, left axis) and Gini Index (right axis) for labor income. Buenos Aires. 1974-2014

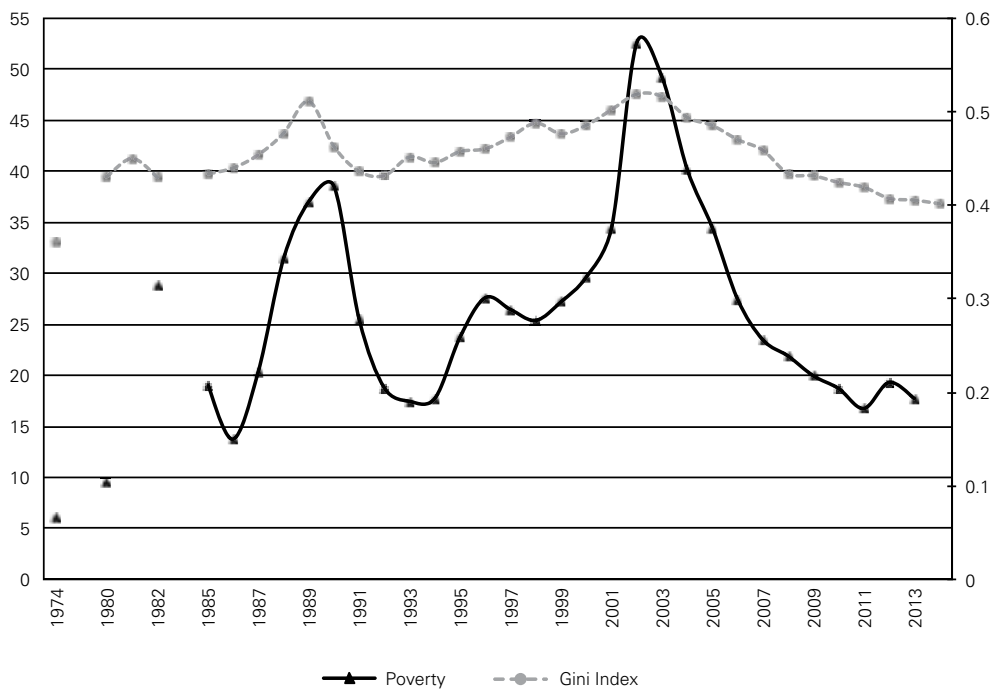

Source: Data compiled by the author based on Household Survey (EPH-INDEC) and Arakaki (2015)

The only possible outcome of a process that combines decreasing real wages and unemployment, with greater income inequality is the growth in the incidence of poverty. As we can see in Chart 8, poverty has seen a negative long-term trend in Argentina between 1974 until 2003 (Arakaki, 2015). By mid-seventies under 5\% of households in Buenos Aires received incomes under the poverty line but by 2003 that figure rose to $40 \%{ }^{14}$.

\section{The last decade}

If we take into consideration the last decade since the crisis, two different stages appear from 2003 until 2007 and since. In the first one, economic growth was impressive, reaching an annual $8 \%$ rate, creating a massive amount of new jobs that reduced the unemployment rate from $24.9 \%$ in late 2002 to $8.8 \%$ by mid-2007. On top of that, real wages grew an impressive $30 \%$ in the period, and workers not protected by social security fell from $44.1 \%$ to $38.7 \%$. On Chart 5 and 6 , we see that the effect was important on the smaller establishment, reducing the gaps of wages and precariousness rate. The combined effects of these processes reduced, by late 2007 , inequality (from 0.52 to 0.46 ) and poverty (to $23 \%$ ) In the second stage, since 2007 , the trends exhibited by real wages, employment and formalization decelerated, hence poverty stagnated (Charts 2, 4, 7 and 8).

${ }^{14}$ The peak showed in 1989 is due especially to the $5.000 \%$ hyperinflation suffered in that year. 
To find the explanation to the change in trend we need to unravel the foundations of the economic scheme of the decade.

Given the structural characteristics of Argentina - important productivity gap and internal heterogeneity - the economy grew at that quick pace due to a combination three factors: 1 ) historically high prices of primary exports (with the reintroduction of export taxes and tariff subsidies), 2) a set of policies aimed at the protection of domestic productive sectors (mainly but not exclusively, depreciated real exchange rate) and 3) invigorated aggregate demand (massive welfare progra$\mathrm{ms}$, promotion of collective bargaining and public works). Nevertheless, as no coherent industrial policy came into effect, neither the productive gap nor the need for compensations have been reduced. On the other hand, since 2007, the sources of extraordinary surplus were unable to sustain economic growth: 1) international prices declined after 2008 and the State was unable to increase taxes on exports, 2) foreign debt has not been available due to the "holdout" trial in New York and 3) real wages recovered their pre-crisis levels ${ }^{15}$. Overall, Argentina could not manage to continue compensating the productive lag, reducing economic growth, job creation, income redistribution and poverty reduction.

Therefore, if we take an historical look on where Argentina stands in labor market conditions we will see that in every case we are in much better shape than in the 2002 crisis. Nevertheless, we are still a long way from the historical data of 1974; this is, in 40 years, Argentina has been going the wrong way. Real wages even taking into account the increase in the last decade are still only $80 \%$ of what they were in the seventies (Chart 3). Labor precariousness is still around 33\% after falling remarkably but up from $20 \%$ in the seventies (Chart 4). On top of that, the stagnation in wages and employment has maintained poverty incidence, according to private surveys, around $20 \%$; that is four times greater than 1974 .

\section{SOME CONCLUSIONS TOWARDS A DEVELOPMENT STRATEGY}

Achieving long-term growth in real wages is the only way to provide better living standards for the population. In order to achieve this, the only possibility is to develop a productive sector and companies that are able to compete in the global market without requiring compensations, especially those received from lower wages and worse working conditions.

The structural limitations are so strong that the strategies applied in the last four decades in Argentina are too simplistic, hence wrong. The neoliberal scheme that stated that market deregulation would raise efficiency and thus send the country towards development has been, after decades of poverty and suffering, proven

\footnotetext{
${ }^{15}$ We are not speaking on behalf of wage moderation. On the contrary, we are just stating that the lack of a comprehensive economic policy aimed at correcting the defective productive structure Argentina has imposes a permanent limit to wages and working conditions.
} 
wrong. The "Keynesian rebirth" experienced since the 2002 crisis that focuses on expanding aggregate demand has achieved lower unemployment and economic growth. However, now that the international crisis continues and export prices have fallen, we need to face the structural deficits of our economies, which is the only thing that can lift the limits our country faces and eradicate poverty.

In the past, this developmental discussion was linked to industrialization. Manufacturing was supposed to be the key for development because of the extended economies of scale and scope, tradability, and employment linkages. However, literature shows that there are other sectors worth promoting. In addition, economic and social development requires several of them in order to create the amount of decent jobs any country needs.

However, the main issue is the characteristics of the companies to encourage. Elsewhere we showed that Argentina has indeed undergone a process of de-industrialization (measured in terms of the weight of the sector in output or employment) since the seventies but it was similar to those experienced in other countries like the U.S., France and Japan (Kennedy and Graña, 2010). The main difference between both sets of countries is the characteristics of the surviving companies, in the latter, that process expresses outsourcing and the complexity of production processes, in our country expresses the inability to compete and complete dismantling of the sector (Fajnzylber, 1983; Nochteff, 1991). Presbich, one of the promoters of Latin America industrialization, already noted the importance of reaching international productive standards in order to improve, and not worsen, living conditions (Prebisch, [1949] 1986).

Anyway, in pursuit of this goal Latin America has an extraordinary source of income, ground rent, on a scale with few comparisons in the world (Iñigo Carrera, 2007). The question, then, lies on how to tax it and especially how and where to apply it.

However, worldwide regulation on wages and labor conditions are required in order to prohibit the slavery like exploitation of workers in poor countries. The tragedies in labor-intensive factories around the underdeveloped world speak for itself. Not only for those workers, but also for the impact that the possibility - and threats - of delocalization causes in labor markets of other countries - both developed and developing-, on union's power and collective bargaining potential. Accomplished that, we need to implement stricter labor regulations, higher enforcement and accomplish higher wages on a regional scale in order to prevent "races to the bottom".

Even in that context, Argentina - as well as other countries in different developing regions - faces structural limitations to enhance their labor markets. The state cannot fully enforce tougher regulations - even if we consider it corruption free - and unions cannot negotiate higher wages - even considering Argentina mighty organizations - because most SMEs do not have the productivity necessary to compete in those conditions. That is particularly important when you notice that those companies employ the vast majority of workers. That is also why our countries are every day struggling between the two sides of a terrible dichotomy: bad 
quality employment or all out unemployment. Worst of all, even if the domestic heterogeneity is important, even more important is the international productivity gap that implies that those SMEs are so unproductive that the wages they can pay are well below poverty lines. This part of the equation for decent jobs and inclusive labor markets lies in macroeconomic and industrial policy realm.

Finally, some trends in motion create some hope. The current and successful evolution of Asian development experiences imply that in the next decades not only primary exports from Latin America will have sustained prices but also that the increase in wages in those countries will reduce the downward pressure on the conditions of work and wages in our region.

\section{REFERENCES}

Arakaki, Agustín (2015), “La pobreza por ingresos en Argentina en el largo plazo”, Realidad Económica $N^{\circ} 289$, IADE, $1^{\circ}$ de enero - 15 de febrero, pp. 85-107. ISSN: 0325-1926

Beccaria, Luis and Roxana Maurizio (2008) "Mercado de trabajo y distribución personal del ingreso" en Lindenboim, J. (comp.) 2008 Trabajo, ingresos y politicas en Argentina. Contribuciones para pensar el siglo XXI, Eudeba, Buenos Aires.

Braun, Oscar and Leonard Joy (1968) "A model of economic stagnation. A case study of the argentine economy”, The economic Journal, Vol. 78, No 312, December, pp - 868-887.

Cimoli, Mario (ed.) (2005) Heterogeneidad estructural asimetrías tecnológicas y crecimiento en América Latina, CEPAL-BID, Santiago de Chile.

Danani, Claudia and Javier Lindenboim (2003) "Trabajo, política y políticas sociales en los 90: ‘hay algo de particular en el caso argentino?” in Javier Lindenboim y Claudia Danani (coord.) Entre el trabajo y la política, Editorial Biblos, Buenos Aires.

Dickens, William and Kevin Lang (1984) A test of dual labour market theory, NBER working paper series, $\mathrm{N}^{\circ} 1314$, NBER, March.

Dosi, Giovanni (1988): "Sources, procedures, and microeconomic effects of innovation" Journal of Economic Literature, Vol. XXVI, pp. 1120-1171.

Fajnzylber, Fernando (1983): La industrialización trunca de América Latina, Centro Editor de América Latina, México.

Fröbel, Folker, Juergen Heinrichs y Otto Kreye (1982) The New International Division of Labour Structural Unemployment in Industrialized Countries and Industrialization in Developing Countries, Cambridge University Press.

Graña, Juan Martin (2015): "Evolución comparada del sector industrial argentino y estadounidense, entre el rezago productivo y el deterioro salarial”, Revista H-industri@, N 17.

Graña, Juan Martin (2013), Las condiciones productivas de las empresas como causa de la evolución de las condiciones de empleo. La industria manufacturera en Argentina desde mediados del siglo XX, PhD Thesis, University of Buenos Aires, Buenos Aires.

Graña, Juan Martin y Alejandro Lavopa (2008): 15 años de EPH, una serie. Empalme entre sus versiones puntual y continua, 1992 - 2006, Documento de Trabajo No 11, CEPED, Buenos Aires.

Graña, Juan Martin and Damian Kennedy (2008) Salario real, costo laboural y productividad. Argentina 1947-2006. Análisis de la información y metodología de estimación, Documento de Trabajo No 12, CEPED, Buenos Aires.

Hart, Keith (1973) "Informal income opportunities and urban employment in Ghana", The Journal of Modern African Studies, Vol. 11, No 1, Cambridge University Press, pp. 61-89.

Iñigo Carrera, Juan (2004): El capital: razón histórica, sujeto revolucionario y conciencia, Ediciones Cooperativas, $3^{\circ}$ Edición, Buenos Aires. 
Iñigo Carrera, Juan (2007) La formación económica de la sociedad argentina. Volumen I: Renta agraria, ganancia industrial y deuda externa. 1882-2004, Imago Mundi, Buenos Aires.

Kennedy, Damian y Juan Martin Graña (2010) “El empobrecimiento de los trabajadores como fuente de excedente en economías con débil dinámica productiva. Argentina desde mediados del siglo XX”, Revista Pecunia No 10, Universidad de León, León (pp. 231-263) (ISSN: 1699-9495)

Lavopa, A. (2007): Heterogeneidad de la estructura productiva argentina: impacto en el mercado laboral durante el periodo 1991-2003, Documento de Trabajo N 9, CEPED, Buenos Aires.

Lewis, Arthur (1954) "Economic Development with Unlimited Supplies of Labour," Manchester School of Economic and Social Studies, Vol. 22, pp. 139-91.

Marx, Karl ([1894] 2007): El capital. Crítica de la Economía Política. Tomo III. Buenos Aires: Siglo XXI Editores.

Nochteff, Hugo (1991) "Reestructuración industrial en la Argentina: regresión estructural e insuficiencias de los enfoques predominantes”, Revista Desarrollo Económico, Vol. 31, № 123, IDES, Buenos Aires, octubre-diciembre.

Pinto, Anibal (1973) "Heterogeneidad estructural y modelos de desarrollo reciente de la América Latina”, en Pinto, A. Inflación: raíces estructurales, Fondo de Cultura Económica, México, D.F.

Portes, Alejandro y Saskia Sassen-Koob (1987) "Making it underground: comparative material on the informal sector in western market economies" American Journal of Sociology, Vol. 93, N 1, The University of Chicago Press, pp. 30-61.

PREALC (1978) Sector informal. Funcionamiento y políticas, OIT, Santiago, Chile.

Prebisch, Raul ([1949] 1986): "El desarrollo económico de la América Latina y algunos de sus principales problemas”, Revista Desarrollo Económico, Vol. 26, No 103, IDES, Buenos Aires, octubre-diciembre.

Ricardo, David ([1817] 2004): Principios de Economía Política y Tributación. México D.F.: Fondo de Cultura Económica.

Shaikh, Anwar ([1991] 2006): Valor, acumulación y crisis. Ensayos de economía política, Ediciones ryr, Buenos Aires.

Starosta, Guido (2010) "Global commodity chains and the Marxian law of value", Antipode, Vol. 42, $\mathrm{N}^{\circ}$ 2, Editorial Board, pp. 433-465.

Vitelli, Guillermo (2012) Los dos siglos de la Argentina: historia económica comparada, Ediciones CCC-Universidad Nacional de Quilmes, Buenos Aires. 